\title{
TREND OF PROFIT MANAGEMENT IN THE COMPANY FINANCIAL AND NON FINANCED REGISTERS IN INDONESIA EXCHANGE
}

\author{
Okti Duwi Lestari. ${ }^{1}$, Yuli Chomsatu Samrotun. ${ }^{2}$ \\ Batik Islamic University, Indonesia \\ Oktiduwi11101993@gmail.com
}

\begin{abstract}
This study aims to determine the tendency of earnings management in financial and non-financial companies listed on the Indonesia Stock Exchange. This Analysis uses independent variables of institutional ownership, audit committee, independent commissioner, audit quality and leverage as well as for the independent variable earnings management. The datasource of this research is quantitative data obtained from andiinon-finance (hotels \& tourism) for the 2016-2018 period. The research method uses purposive sampling and statistical methods using multiple linear regression analysis. The sample of this study was 10 insurance companies and 7 hotels \& tourism companies within a period of 3 years producing 51 samples. The results of this study indicate that the tendency of earnings management is more influenced byinsurance companies, institutional ownership variables independent commissioners and leverage have an effect on earnings management and audit committee variables and audit quality have no effect. Whereas The influential hotel \& insurance company variables are only independent commissioners and audit quality.
\end{abstract}

Keywords: Earnings Management, institutional ownership, audit committee, independent commissioner, audit quality leverage

\section{INTRODUCTION}

Earnings management is an emphasis on the importance of handing over the company's operational responsibilities from the owner to other parties who have better management skills. Submission of responsibility must be through the delivery of information, imbalance in the delivery of information where managers have more information can lead to conflict, the greater the information asymmetry, the greater the impetus for managers to apply opportunistically.

Earnings management practices can be influenced by various factors. There have been many studies on earnings management that resulted in various independent variables. Researchers in this study will only examine several factors, namely institutional ownership, audit committee, independent commissioner, audit quality and leverage. The reason researchers chose the mechanism factor of good corporate governance, because this issue is being discussed hotly as a tool that can solve problems in the management and accountability of modern companies (Arlita, Bone, \& Kesuma, 2019). For example, an independent commissioner is a representation of a minority interest. Its existence is made as a protector from the possibility of information asymmetry and management opportunistic actions towards the principal. It is expected that the problems that will arise are expected to be limited or even minimized. While the selection of other factors, namely leverage because leverage is calculated based on the formula of the ratio of debt and assets has a close relationship with earnings management. The higher the level of debt owned by a company, this will encourage management to conduct earnings management.

This study uses two sectors of the company, namely financial companies with insurance and nonfinancial sub-sectors hotel, restaurant and tourism because the subsector has sufficient influence on the Indonesia 
Stock Exchange, besides these companies have a complete component to calculate management value profit. Previous research obtain different results for example research Guna \& Herawaty, (2017) states that audit quality and leverage affect earnings management and for independent commissioners, audit committees and managerial ownership have no effect on earnings management and are not in line with Yolanda, Hapsari, Akbar, Herawaty (2019) his research with audit quality variables had no effect on earnings management. Arlita, Bone, \& Kesuma, (2019) from their research stated that institutional ownership and independent commissioners have a significant effect on earnings management and leverage does not affect earnings management. Based on the results of Astari \& Suryanawa's research (2017) shows that managerial ownership and institutional ownership have a negative and significant effect on earnings management, this means that increasing managerial ownership and institutional ownership decreases earnings management measures, company size, leverage, profitability and sales growth has a positive and significant effect on earnings management, this means that the higher the company size, leverage, profitability and sales growth, the more increased earnings management actions. From the empirical evidence of previous research there are many factors that affect earnings management both from the characteristics of corporate governance as well as leverage and profitability, but many of the results of some of these variables have inconsistencies. Therefore, this study is intended to reconfirm variables that affect earnings management further. The variable uses institutional ownership, audit committee, independent commissioner, audit quality and leverage. This study also uses different periods and uses different companies, here the study uses two corporate sectors, namely non-financial and financial, which ultimately as a comparison of companies from which sector is more likely to influence earnings management. Based on the differences in previous studies, this study will provide empirical findings that are different from previous studies. So the authors are interested in taking the title "Trend of Profit Management in Financial and Non-Financial Companies Registered on the Stock Exchange". here the study uses two corporate sectors, namely non-financial and financial, which ultimately as a comparison of companies from which sector is more likely to affect earnings management. Based on the differences in previous studies, this study will provide empirical findings that are different from previous studies. So the authors are interested in taking the title "Trend of Profit Management in Financial and Non-Financial Companies Registered on the Stock Exchange". here the study uses two corporate sectors, namely non-financial and financial, which ultimately as a comparison of companies from which sector is more likely to affect earnings management. Based on the differences in previous studies, this study will provide empirical findings that are different from previous studies. So the authors are interested in taking the title "Trend of Profit Management in Financial and Non-Financial Companies Registered on the Stock Exchange". Theoretical Foundation, agency Theory Describes the relationship between investors or shareholders as actors and managers as agents. Management is responsible to investors regarding their work or performance. Jensen and Meckling (1976) in Giovani, (2017) describe agency relations as a contract in which one or more people (principals) engage other people (agents) to perform some services on their behalf that involve the 
delegation of some authority to make decisions to agents

One way to monitor agency relationships is through corporate governance mechanisms. Conditions Where the company reported by the manager is not in accordance with the actual situation due to differences in information held between managers and shareholders therefore corporate governance is directed at reducing information asymmetry between principals and agents Earnings management is the effort of company managers to intervene or influence information in financial statements with the aim of tricking stakeholders who want to know the performance and condition of the company (Sulistyanto, (2008) in Ermawati, Maslichah, \& Anwar, (2020). Profit Management arises because of the principal relationship with the agent, which can lead to problems due to the principle of work relations, namely shareholders and parties who receive authority. Earnings management is used by a company to increase or decrease the current reported earnings of a unit for which the manager is responsible without causing an increase or decrease in long-term economic profitability (Pradana, 2018).

There are several motivations of the existence of earnings management actions (Fatimah, 2019), namely: Bonus purposes, Political Motivation, Taxation motivations, CEO change Initial Public Offering (IPO), Important Provide information to investors

It was concluded that the manager is a person who is able to influence the occurrence of earnings management. When managers report performance that differs from the company's basics, managers make it more difficult for investors to identify earnings andperformance management behaviors. Managers are very strategic in influencing and making it difficult for investors to understand the value that is in each company.

Institutional Ownership ,Instituti onal Ownership is the level of share ownership by an institution in a company, measured by the proportion of shares owned by the institution at the end of the year expressed as a percentage. Jensen and Mecking (1976) in Giovani (2017) institutional ownership has an important message in avoiding agency conflicts between shareholders and managers. The existence of institutional investors is able to carry out a good oversight mechanism in every manager's decision. That is because institutional investors interfere in important decision making so it is not easy to believe in earnings manipulation behavior. Anggraeni \& Hadiprajitno, (2013) states that institutional ownership is considered to be able to reduce earnings management practices because it considers institutional as a sophisticated investor to monitor management whose impact will reduce managers' motivation to conduct earnings management. Initial Research, (2019) states that institutional ownership variable has no effect on earnings management, institutional ownership cannot carry out its role effectively in mitigating earnings management. The greater institutional ownership makes the owner can act according to his own interests.

The Audit Committee provides more oversight of the company's management performance and provides accurate information precisely and assists the board of commissioners in analyzing the company's financial statements. The role of the audit committee is also to delegate responsibility to the committee, in terms of monitoring the financial policies of management, the audit committee tends to provide the greatest protection for shareholders in maintaining the credibility of the company's financial statements because of special 
monitoring of financial reporting and audit activities provided by the audit committee. Results of Research conducted by Raihan \& Herawaty, (2019) the audit committee affected earnings management while Anggoro, (2017) the audit committee did not affect earnings management.

The Independent Board of Commissioners is the highest internal control mechanism responsible for monitoring the actions of top management (Fama and Jensen 1983). The independent Board of Commissioners as a corporate organ has a collective duty and responsibility to supervise and provide advice to directors and ensure that the company implements GCG (KNKG, 2006). However, the board of independent commissioners may not participate in making operational decisions. The position of each member of the board of commissioners including the chief commissioner is equal. Arlita, Bone, \& Kesuma (2019) in their research explained that the board of commissioners influences earnings management, which means that the higher the level of the independent board of commissioners, the higher the earnings management. But on the contrary, research by Fitriani, Affan, \&

Auditor quality reflects the auditor's ability to detect and report materialerrors found in the presentation of financial statements. The better the quality of the audit, is expected to increase shareholder confidence in the information presented in the financial statements. Because, qualified auditors, will not risk their good name by giving a fair opinion on the financial statements in which there are indications of earnings management practices. The quality of the Auditor is measured by the proxy of the KAP size, because it is assumed to have an effect on the results of audits by the auditor. An audit conducted by a big four KAP is interpreted as better quality than that by a non-big four KAP Research conducted by Satrio, Oktaroza, \& Purnamasari, (2018) which proves that the measure of CAP has a significant positive effect on earnings management. However, it contradicts research conducted by Anggoro, (2017) results which show that KAP size has a negative and significant effect on earnings management.

Leverage used to determine the impact of debt contracts on earnings management (Shen and Chih, (2007) in Amalia, Wijaya, \& Widiasmara, (2019)) If the Leverage Level is greater then the value of the debt owned by the company will also be higher. by inaccurate application of strategies or financial management mistakes by management.

Lack of Supervision can provide a great opportunity to manage earnings which occurs due to the high leverage in order to maintain its performance in the eyes of shareholders (Amalia, Wijaya, \& Widiasmara, 2019). There is research on the effect of leverage on earnings management, Prime research, (2019) states that leverage affects earnings management, while it is not in line with the research of Azis, Herwinarni, \& Saputri, (2016) resulting in leverage not affecting earnings management.

Based on the literature review explanation above, this research hypothesis can be formulated, namely:

$\mathrm{H} 1$ :Ownership Institutional influence on earnings management significantly.

H2 :Influential audit committee significant effect on earnings management.

H3 :Independent commissioner has significant influence towards earnings management.

H4 :Quality audit significant effect on earnings management.

H5 :Leverage significant effect on earnings management. 


\section{METHODS \\ Population and Samples}

The population used in this study is financial companies (Insurance subsector) and non-financial companies (Hotel and Tourism sub-sector) which are listed on the Indonesia Stock Exchange. The sample used the company's 2016-2018 financial statements with the sampling technique using purposive sampling method, the samples obtained were 51 samples.

\section{Dependent and Independent Variables}

Earnings management

Earnings management is the dependent variable. Profit Management according to Anggoro, (2017) opportunistic behavior of managers to manipulate the numbers in the financial statements in accordance with the objectives to be achieved. Taking the Jones model earnings management formula for non-discretionary accruals in the relevant year is (Suryono, 2017):

NDAt $=\alpha 1(1 / A t-I)+\alpha 2\left(\Delta R V_{t}\right)+\alpha 3$ (PPEt)

$$
\begin{aligned}
& \text { Information: a } \\
& \triangle R E V \text { =income in year minus }
\end{aligned}
$$

$\alpha 1, \alpha 2, \alpha 3=$ company specific parameters.

Estimation of companyspecific parameters $(\alpha 1, \alpha 2, \alpha 3)$ is generated using the following model in the estimation period (Jones, 1991):

TAt $=\mathrm{a} 1 \quad(1 / A t-I)+\mathrm{a} 2 \quad(\Delta \mathrm{REVt})+\mathrm{a} 3$ (PPEt) + ut,

Where: a1, a2, and a3 show the estimated regression coefficients of $\alpha 1, \alpha 2$, and $\alpha 3$. Whereas TA is the total accrual divided by the total year $\mathrm{t}-1$.

Institutional Ownership
Institutional ownership is ownership of a company by an institution that is incorporated (Perdana, 2019). To calculate institutional ownership by dividing the number of institutional ownership shares by the number of shares outstanding (Radiman \& Mawaddah, 2019).

\section{Audit Committee}

The committee is independent and is formed by the board of commissioners whose task is to assist the board of commissioners' functions in carrying out the oversight function of risk management, financial reporting of audit funds in companies. This variable is measured numerically, which is seen from the nominal number of audit members (Anggraeni \& Hadiprajitno, 2013).

Komite Audit $=\sum$ Anggota Komite Audit di Perusahaan

Independent Commissioner Independent commissioners are members of the board of commissioners who have no affiliation with other members of the board of commissioners, members of the board of directors, and controlling shareholders. Independent Commissioners are measured using a ratio (Giovani, 2017):

Komisaris Independen $=\frac{\text { Jumlah Komisaris Independen }}{\text { Jumlah Seluruh Dewan Komisaris }}$

Audit Quality

Any possibilities that can occur when the auditor audits the client's financial statements and finds violations or errors that occur and report them in the audited financial statements (Damayanti \& Susanto, 2015). Audit quality is measured by proxy of KAP size. Audit quality measurement uses a dummy variable (Amalia, Wijaya \& Widiasmara 2019) that will be given a number 1 if the company's financial statements are audited by 
the big four KAP and will be given a number 0 if the company's financial statements are audited by a non-big four KAP.

\section{Leverage}

Use of a number of assets or funds by companies where in the use of these assets or funds, companies must incur fixed costs. Leverage Ratios are calculated using total Debt to Total Capital Asset (TDCA). The purpose of leverage is to measure the portion of assets used to guarantee overall liabilities or debts. Leverage Measured using a ratio (Utami \& Meiranto, 2017):

AktivaLancar +HutangJangkaPanjang

Lev=

$$
\text { JumlahAktiva }
$$

\section{Hypothesis Testing Method}

Data analysis used in this research is multiple linear regression analysis with the following equation:

$\mathrm{ML}=\alpha+\beta 1 \mathrm{~K}$.Ins $+\beta 2 \mathrm{Kom} . A+\beta 3$ K.Ind $+\beta 4$ Kua. $A+\beta 4 \operatorname{Lev}+\mathrm{e}$

\section{RESULTS AND DISCUSSION Descriptive General Data Research}

The study was conducted on insurance companies and tourism hotels listed on the 2016-2018 IDX. Sampling Using Purposive sampling to get 51 company financial statements from 17 companies, 10 insurance companies and 7 hotel tourism companies. Data obtained through www.idx.co.id.

\section{Classic assumption test Normality test}

Normality test is used to determine whether the data meets the normal assumptions or not. If the sig (2tailed) value $>0.05$ then the data distribution is normal and vice versa. The normality test output above can be seen that the significance (Asymp.Sig) is 0.824 and 0.033 because the significance is > 0.05 , so it is concluded that the data are normally distributed and the regression model is suitable for research data use.

\section{Multicollinearity Test}

Multicollinearity test is conducted to test whether the data is free from multicollinearity symptoms. If the tolerance value $>0.05$ and VIF value $<5$, it means that there is no multicollinearity of the tested data and vice versa. The results of the multicollinearity test output tolerance value of each independent variable of insurance companies and hotels and tourism are more than the 0.05 standard and the VIF value of each variable also has a value of no more than 5. Therefore concluded there is no multicollinearity between variables in the regression model.

\section{Autocorrelation Test}

The knowing test aims to find out whether there is a deviation from the classic assumption of autocorrelation. Autocorrelation test in research uses the Run test. If the Asymp Value. Sig. (2-tailed) $<0.05$, there are symptoms of autocorrelation and vice versa. The autocorrelation test results above concluded that there were no autocorrelation symptoms because the value of the Asymp. Sig exceeded the standards of 0.853 and $0.727>$ 0.05 .

\section{Heteroscedasticity Test \\ Heteroscedasticity}

Test

Performed to test the data that there are variance in residual variance for all observations in the linear regression model. If the heteroscedasticity assumption is not met, then the regression model is declared invalid as a forecasting tool. It said that there were no symptoms of heteroscedasticity, significant values $>0.05$ and vice versa. Results of the heteroscedasticity test output 
concluded the regression model is free from heteroscedasticity problems. This can be seen from the significancevalue of the independent variables greater than the standard that is 0.05 .

\section{Test Regression Analysis}

Multiple Linear Regression Model

Data Analysis Used in this research is multiple linear regression analysis with the following equation:

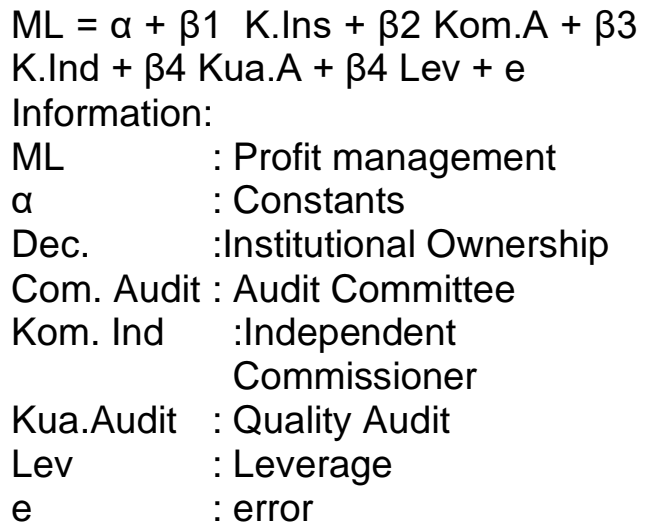

Table 1. Multiple Linear Equation Test

\begin{tabular}{lcc}
\hline & & \\
& Insurance & Hotel \& Tourism \\
\hline \multicolumn{1}{c}{ (Constant) } & 1,290 & .205 \\
Institutional Ownership & $-0,338$ & -0.004 \\
Audit Committee & .221 & $-0,029$ \\
Independent Commissioner & $-0,511$ & $-0,234$ \\
Audit Quality & $-0,305$ & 0.041 \\
Leverage & .702 & .143 \\
\hline
\end{tabular}

Source: Appendix 1

Based on the results of the table above, the analysis of multiple linear regression can be written as follows: $M E=1,290-0,338$ Kep. Inst + 0,221 Kom. Audit - 0,551 Kep. Ind - 0,305 Kua. Audit + 0,702 Lev + e

$\mathrm{ME}=0.205-0.004$ Kep.Inst 0.029 Comm. Audit - 0.234 Kep.Ind +0.041 Kua. Audit $+0.143 \mathrm{Lev}+\mathrm{e}$

\section{Model Feasibility Test \\ Model Feasibility Test or $\mathrm{F}$ test \\ is used to test the effect of all}

independent variables simultaneously or simultaneously with the following conditions: Institutional ownership, audit committee, independent commissioners, audit quality and leverage have positive or negative effects in terms of its Beta coefficient. Significance The influence will be seen from the $p$-value at the level of significance $(\alpha) a=0.05$ with criteria, if $p$-value $<0.05$ then it has a significant effect on earnings management and vice versa.

Table 2. Model Feasibility Test

\begin{tabular}{|c|c|c|c|c|c|}
\hline Comp & $F_{\text {count }}$ & $\mathrm{F}_{\text {Table }}$ & Sig & Std & Info \\
\hline Insur & 3,823 & 2.76 & 0.011 & 0.05 & \multirow{2}{*}{$\begin{array}{l}\text { The model } \\
\text { used is fit } \\
\text { or fit }\end{array}$} \\
\hline $\begin{array}{l}\text { Hotel \& } \\
\text { Parw }\end{array}$ & 3,923 & 2.71 & 0.008 & 0.05 & \\
\hline
\end{tabular}

Source: attachment 2

The output results above can be seen that the value of F-count data for insurance companies is 3.823 with a probability of 0.11 , this shows that the research model can beaccepted because the significance value is 
less than 0.05, while hotel \& tourism company data is 3.923 with a probability of 0.008 , this shows that the research model is also acceptable because the significant value is smaller than 0.05 .

\section{Hypothesis Test ( $t$ test)}

Hypothesis test or $t$ test is used to determine the effect of the independent variable on the dependent variable partially.

Table 3. Hypothesis Test (t test) Insurance compan

\begin{tabular}{lccccl}
\hline \multicolumn{1}{c}{ Var. } & Thitung & Ttable & Sig & Std & Ket. \\
\hline K. Ins & 3,031 & 2,063 & 0.006 & $<0.05$ & rejected \\
Km. A & 1,369 & 2,063 & .184 & $<0.05$ & received \\
K. Ind & 2,255 & 2,063 & 0.033 & $<0.05$ & rejected \\
Kua A & 0.021 & 2,063 & .983 & $<0.05$ & received \\
Lev & 2,653 & 2,063 & 0.014 & $<0.05$ & rejected \\
\hline
\end{tabular}

Source: Appendix 3

Table 3. Hypothesis Test (t test) Hotel \& Tourism Company

\begin{tabular}{lcccclc}
\hline \multicolumn{1}{c}{ Var. } & titung & Ttable & Sig & Std & & t. \\
\hline K. Ins & 1,196 & 2,051 & .241 & $<0.05$ & received & \\
Km. A & .681 & 2,051 & 0.501 & $<0.05$ & received & \\
K. Ind & 2,659 & 2,051 & 0.013 & $<0.05$ & rejected & \\
Kua A & 3,087 & 2,051 & 0.004 & $<0.05$ & rejected & \\
Lev & 0.037 & 2,051 & 0.970 & $<0.05$ & received & \\
\hline
\end{tabular}

Source: Appendix 3

From the table it is known that the insurance company data variable institutional ownership, independent commissioners and leverage affect earnings management and audit committee variables and audit quality does not affect earnings management. Whereas for hotel and tourism company data the variables that are able to influence earnings management are independent commissioners and audit quality and which do not affect institutional ownership variables, audit committee and leverage.

Table 4. Adjusted Determination Coefficient Test

\begin{tabular}{lccccl}
\hline Comp & Mdl & $\mathrm{R}$ & $\mathrm{R} 2$ & $\begin{array}{c}\text { Adj } \\
\mathrm{R} 2\end{array}$ & \multicolumn{1}{c}{ Info } \\
\hline Insur & 1 & .666 & .443 & .327 & $\begin{array}{l}\text { The independent } \\
\text { variable can } \\
\text { explain the } \\
\text { variation of the } \\
\text { dependent variable }\end{array}$ \\
$\begin{array}{l}\text { Hotel \& } \\
\text { Parw }\end{array}$ & 1 & 0.649 & 0.421 & 0.314 &
\end{tabular}

The table above R-square value of 0.443 for insurance company data shows the proportion of the influence of all independent variables on

\section{Adjusted Determination Coefficient Test (R2)}

The adjusted R2 coefficient determination test is carried out to measure the extent of the independence variable in explaining the dependent variable. The contribution value of the coefficient of determination test is $0>\mathrm{R} 2>1$. If there is a value of $\min (-)$, it is said that there is no influence between the independent variable and the dependent variable. 
external variables that do not belong to this regression model. Data of hotel and tourism companies are also not much different R-square value of 0.421 shows the proportion of the influence of all independent variables on the dependent variable $42.1 \%$ all independent variables affect the dependent variable the remaining $57.9 \%$ is influenced by variables outside the regression model.

\section{Discussion of Data Analysis Results Effect of Institutional Ownership on Earnings Management}

Data of insurance companies prove that institutional ownership variable influences earnings management with a value of $t$ arithmetic 3.031 greater t-table 2.063 which means that h0 is rejected and value is smaller than standard (0.006 $<0.05)$ which means h0 is accepted. While for hotel and insurance company data, institutional ownership variable has a t-count value of 1.196 and t table 2.051 means that h0 is accepted, while a-value $0.241>0.05$ means that $h 0$ is rejected, it is concluded that institutional ownership variable has no effect on earnings management.

$$
\text { Data from insurance }
$$

company institutional ownership variables indicate an effect on earnings management. This shows that the greater the percentage, the greaterthe chance for the occurrence of earnings management practices in a company. The inclusion of Managers from the majority shareholders of institutional ownership in the management of the company, so any decision may only benefit the majority shareholders, it will provide opportunities for earnings management.

The variable Institutional Ownership has no effect on earnings management obtained from hotel and tourism company data, this suggests that increasing ownership will be able to monitor the manager's performance in managing the company so that it can limit management's actions in carrying out earnings management audit activities (Ramli \& Stephani, 2019). Earnings Management tends to be influenced by institutional ownership variables more on insurance company data. This is due to the large number of shareholders who have a majority in the company, so that majority shareholders can act in their own interests.

\section{Influence of the Audit Committee} Towards Profit Management

Insurance company data proves that the audit committee variable has no effect on earnings management with a t-count value of 1.369 smaller than t-table 2.063 which means that h0 is accepted and the value of value is greater than the standard $(0.184>0.05)$, which means h0 is rejected. Whereas for hotel and insurance company data the audit committee variable has a t-count value of 0.681 smaller t-table 2, 051 means that h0 is accepted, while $\rho$ value $0.501>0.05$ means $h 0$ is rejected, it is concluded that the audit committee variable has no effect on earnings management.

The more the number of audit committee meetings, the more able to reduce earnings management actions taken by company management. The research of Guna \& Herawaty (2017) and Giovania (2017) audit committee has no effect on earnings management. The tendency of the audit committee variable towards earnings management does not affect the data of insurance companies or hotels and tourism, the existence of an audit committee is only limited to the fulfillment of the regulation of funds has not been considered based on the needs of the company that causes the audit committee is still unable to show an independent position which is 
sometimes still influenced by the board of commissioners .

\section{Influence of Commissioners Management.} Insurance proves that commissioner variable

\section{Independent on Earnings} company data the independent influences earnings management with a t-value of 2.255 greater than $\mathrm{t}$-table 2.063 which means that $h 0$ is rejected and $\rho$-value is smaller than the standard $(0.033>0.05)$ which means h0 is accepted. Whereas for hotel and insurance company data the independent commissioner variable has a t-count value of 2.659 greater $t-$ table 2.051 means that h0 is rejected, while a-value $0.013<0.05$ means that ho is accepted and concluded that the independent commissione variable has an effect on earnings management. The independent commissioner variable tends to influence earnings management on insurance company and hotel \& tourism data. This proves that the higher the proportion of independent commissioners, the higher the level of earnings management, Amelia \& Hernawati (2016) states that independent commissioners have a close relationship with earnings management, because the proportion of independent directors in a company is able to reduce earnings management.

\section{Effect of Audit Quality on Earnings Management}

Insurance company data proves that the audit quality variable has no effect on earnings management with a value of t-count 0.021 smaller than ttable 2.063 which means that $\mathrm{h} 0$ is accepted and the value of $\rho$-value is greater than the standard (0.983> $0.05)$ which means h0 is rejected. Whereas for hotel and insurance company data the audit quality variable has a t-count value of 3.087 greater ttable 2.051 means h0 is rejected, while a-value of $0.004<0.05$ means h0 is accepted it is concluded that the audit quality variable influences earnings management.

Audit quality variable on insurance company data has no effect on earnings management. It is also proven by Christiana \& Nugrahanti's research (2014) which proves that audit quality variable has no effect on earnings management, this is possible earnings management practices occur because companies have a desire for performance company finances look good in the eyes of potential investors and ignore the existence of Big Four KAP auditors.

Hotel and tourism company data audit quality variables affect earnings management. Audit quality is measured using KAP size. Companies will prefer KAP with better quality to improve the quality of financial statements, and the company's reputation in the eyes of report users. Rahmawati, Khikmah, \& Dewi (2017) states that companies with high agency costs will tend to use large KAPs to reduce earnings management. The influence of audit quality variables on earnings management in this study, earnings management tends to influence the hotel and company data because most of the company's data uses Big Four KAP. Big Four KAP Considered to be more thorough and careful in doing earnings management.

\section{Effect of Leverage on Profit Management}

Insurance company data proves that the leverage variable influences earnings management with a t-value of 2.653 greater than t-table 2.063 which means that ho is rejected and $\rho$-value is smaller than the standard (0.014> 0.05), which means h0 is accepted. While for hotel and insurance company data the leverage variable has a value of $\mathrm{t}$-count 0.037 smaller t-table 2.051 means that 
h0 is accepted, while $\rho$-value $0.970<0.05$ means h0 is rejected, it is concluded that the leverage variable has no effect on earnings management.

The greater the leverage the greater the amount of debt used by companies to finance assets (Giovani, 2017). Profit Management can be influenced by the level of company debt. Lack of supervision can provide a great opportunity for actions such as earnings management which causes high leverage to maintain performance in the eyes of shareholders (Amalia, Wijaya, \& Widiasmara, 2019).

Leverage No effect on earnings management applies to hotel and tourism company data, this is because companies do not have to rely on earnings management for the security of debt agreements. Zhou and Elder (2004) in (Christiani \& Nugrahanti 2014) stated that there are several things that affect the security of debt agreements, for example the company's credibility, guarantees given by the company and the timely payment of installments. According to Dimarcia \& Krisnadewi (2016) the average company has a safe leverage in the sense that the company is able to pay debts that are used to finance company assets, so managers are not interested or motivated to practice earnings management.

Profit Management is more likely to affect the variable leverage in insurance company data because with a high proportion of debt compared to the proportion of its activities will tend to manipulate in the form of earnings management. This situation indicates that companies with high leverage have weak oversight and management that causes management to make their own decisions and also determine inappropriate strategies.

\section{CONCLUSION}

Based on the description that has been explained in the previous chapter, it can be concluded:
In the insurance company data, institutional ownership variables, independent commissioners and leverage influence earnings management in line with Arlita, Bone, \& Kesuma (2019) and Amalia, Wijaya, \& Widiasmara (2019) while the audit committee variable and audit quality do not affect earnings management the results are in line with Christiani \& Nugrahanti (2014) and Ayem, Suyanto, \& Wahidah (2019). Hotel and tourism company data variables that are able to influence earnings management are independent commissioners and audit quality and which have no effect on institutional ownership variables, audit committee and yield leverage in line with Azis, Herwinarni, \& Saputri (2016) Dana Guna \& Herawaty (2017).

In institutional ownership insurance companies, independent commissioners and leverage affect earnings management, the high level of majority shareholders will make profit manipulation even higher because majority shareholders will act according to their wishes, earnings management can alsobe influenced by the magnitude of the company's debt levels (leverage). Hotel and tourism company independent commissioner variables and audit quality affect earnings management, the existence of an independent commissioner is useful to oversee the company's operations by the management to make an effective contribution to the results of the process of preparing quality financial statements so as to limit earnings management by the company.

\section{REFERENCES}

Amalia, F. Wijaya, AL, \& Widiasmara, A. (2019). The Effect of Profitability and Leverage on Profit Management with GCG as a Moderation Variable. Simba Seminar on Management, Business and Accounting Innovation I. 
Amelia, W., \& Hernawati, E. (2016). The Effect of Independent Commissioners, Company Size and Profitability on Profit Management. Neo Can be Volume 10, No.1, June

Anggoro, S. (2017). Analysis of Factors Affecting Earnings Management (Empirical Study of Financial Companies Listed on the Indonesia Stock Exchange in 2015). Diponegoro University Semarang.

Anggraeni, MR, \& Hadiprajitno, PB (2013). The Effect of Managerial Ownership Structure, Company Size, and Corporate Governance Practices on Earnings Management Diponegoro Journal of Accounting Volume 2, 1-13.

Arlita, R, Bone, H., \& Kesuma, Al. (2019). The Effect of Good Corporate Governance and Leverage on Earnings Management Practices. Accountable Vol 16 No.2.

Astari, AA, \& Suryanawa, IK (2017). Factors That Affect Earnings Management. E-Journal of Udayana University Accounting Vol.20.1. July, 290-319.

Azis, MN, Herwinarni, Y., \& Saputri, RS (2016). Analysis of Factors Affecting Profit Management in Textile and Garment Manufacturing Companies Listed on the Indonesia Stock Exchange in 2011-2015. Permana - Vol. Vii No. February 2

Ayem, S., Suyanto, \& Wahidah, U. (2019). Effects of Adoption of International Financial Reporting Standards (Ifrs) and Good Corporate Governance on Earnings Management. Jemma Journal of Economic Management and Accounting.

Christiani, I., \& Nugrahanti, Y.aW. (2014). Effect of Audit Quality on Earnings Management. Journal of Accounting and Finance, Vol. 16, No. 1, May, 52-62.

Damayanti, F., \& Susanto, T. (2015). Influence of Audit Committee, Audit Quality, Institutional Ownership, Company Risk and Return on Assets on Tax Avoidance. Journal of Business and Management Vol. 5, aNo. 2, October 2015

Dimarcia, NL, \& Krisnadewi, KA (2016). Effects of Operational Diversification, Leverage and Managerial Ownership on Earnings Management. EJournal of Accounting, Udayana University Vol.15.3 June, 23242351.

Ermawati, E., Maslichah \& Anwar, SA (2020). Effect of Compensation, Managerial Ownership, Company Diversification and Cap Size on Profit Management in Manufacturing Companies Listed on the Indonesia Stock Exchange in 2016-2018. E-Jra Vol. 09 No. February 06.

Fitriani, MR, Affan, N., \& Kesuma, A. (2019). The Effect of Good Corporate Governance Implementation on Earnings Management in BUMN Companies Listed on the Indonesia Stock Exchange. Journal of Accounting Sciences Mulawarman Vol 4 No.1.

Giovani, Ma (2017). The Effect of Ownership Structure, Corporate Governance,and Characteristics of the Company on Earnings Management. Journal of Business Accounting, Vol. 15, No. 2, September.

Guna, WI, \& Herawaty, A. (2017). The Effect of Good Corporate Governance Mechanisms, Auditor Independence, Audit Quality And Other Factors On Earnings Management. Journal of Business and Accounting Vol. 12, No. 1, April, p. 53 - 68. 
Palma, I., \& Purba, NM (2020). The Effect of Corporate Governance and Ownership Structure on Profit Management Listed on the Indonesia Stock Exchange. Emba Journal Vol.8 No.1 February, 0616 - 626.

Perdana, AA (2019). Effect of Institutional Ownership, Leverage, Audit Committee Funds on Profit Management in Companies Listed on the Indonesia Stock Exchange (Empirical Study of Companies Listed on the Indonesian Stock Exchange Pt from 2015-2017). Journal of Sakti Economy (Jes) Volume 8 No. June 1.

Raihan, H., \& Herawaty, V. (2019). Factors That Affect Earnings Management With Earnings With the Audit Committee As Moderation Variables. The 5th National Scholar Seminar.

Rahmawati, M.Khikmah, SN, \& Dewi, VS (2017). The Effect of Auditor Quality and Corporate Governance on Earnings Management (Empirical Study of Manufacturing Companies Listed on the Indonesia Stock Exchange in the 2011-2016 Period). The 6th University Research Colloquium, Muhammadiyah University, Magelang.

Satrio, A., Oktaroza, ML, \& Purnamasari, P. (2018). Influence of Audit Quality and Audit Committee on Earnings Management. Bandung Islamic University Repository. 